ISSN (Online) 2710-3315

https://doi.org/10.20535/EHS.2021.233206

УДК 504.062.2

\title{
ЕФЕКТИВНІСТЬ ЗНЕКИСНЕННЯ ВОДИ НА ЗАЛІЗОВМІСТКОМУ РЕДОКСИТІ
}

\author{
А.В. Голяка, М.Д. Гомеля \\ Національний технічний університет України \\ «Київський політехнічний інститут ім. Ігоря Сікорського» \\ пр. Перемоги, 37, Київ, 03056, Україна \\ e-mail: andreykagolyaka@gmail.com
}

До води, що використовується в тепломережах, у водогрійних котлах, парогенераторах, енергетичних системах, включаючи виробництво пари у промисловості та виробництво електроенергії на теплових та атомних електростанціях ставляться жорсткі вимоги не лише щодо стабільності по відношенню до осадоутворення, але і до корозійної агресивності. Тому в процесах підготовки води для теплоенергетичних систем широко використовують методи реагентного та натрійкатіонного пом'якшення, мембранного та іонообмінного знесолення води, додавання інгібіторів корозії та стабілізаторів накипоутворення [1].

Проте при використанні води у водогрійних та парових котлах застосування більшості реагентів небажане або недопустиме. Якщо врахувати, що корозія обладнання та трубопроводів у даному випадку обумовлена кисневою деполяризацією, то найбільш доцільним у запобіганні корозії є використання процесів деаерації води. При наявності кисню у живильних водах котлів та тепломереж у концентраціях більше 50 мкг/дм³ швидкість корозії металів у воді при підвищених та високих температурах є досить значною. За даних умов різко скорочується термін експлуатації обладнання, суттєво зростають витрати на виробництво енергії та транспортування гарячої води. Тому найефективнішим процесом у зниженні корозійної агресивності води в енергетиці $є$ iї глибоке знекиснення перед котлами, теплообмінним обладнанням, при підживленні тепломереж [2].

Метою дослідження було отримання залізовмісних сорбентів кисню, визначення їх ефективності в залежності від швидкості фільтрування води при контролі вмісту заліза у знекисненій воді.

Для досягення поставленої мети вирішувались наступні задачі такі, як створення лабораторної установки для знекиснення води при використанні залізовмісного сорбенту; оцінка ефективності знекиснення води при різних швидкостях фільтрування; визначення впливу $\mathrm{pH}$ середовища на ефективність знекиснення води на залізовмісткому редокситі; оцінка ефективності доочищення води від іонів заліза на катіоніті та від кисню на модифікованому іонами $\mathrm{SO}_{3}^{2-}$ аніоніті.

Процеси вилучення кисню вивчали при фільтруванні води через колонку заповнену подрібненим залізомістким матеріалом в якому вода контактує безпосередньо з металевою поверхнею. Для активації сорбенту в колонці об'ємом $130 \mathrm{~cm}^{3}$ його спочатку обробляли водою $3 \mathrm{pH}=2,5-3,0$. Об'єм пропущеного розчину 5 дм³ $^{3}$ Після цього через колонку із сорбентом

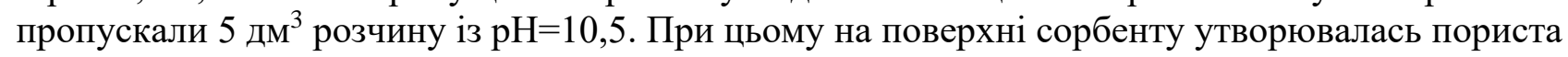


плівка, що складалась 3 гідроксиду заліза $\left(\mathrm{Fe}(\mathrm{OH})_{3}\right)$ та магнетиту $\left(\mathrm{Fe}_{3} \mathrm{O}_{4}\right)$. Даний редоксит використовували шифом МЗ-Ф.

Також була досліджена двостадійна система стабілізації води з використанням катіоніту КУ-2-8 в $\mathrm{Na}^{+}$формі або аніоніту АВ-17-8 в $\mathrm{SO}_{3}^{2-}$ формі (рис.1).
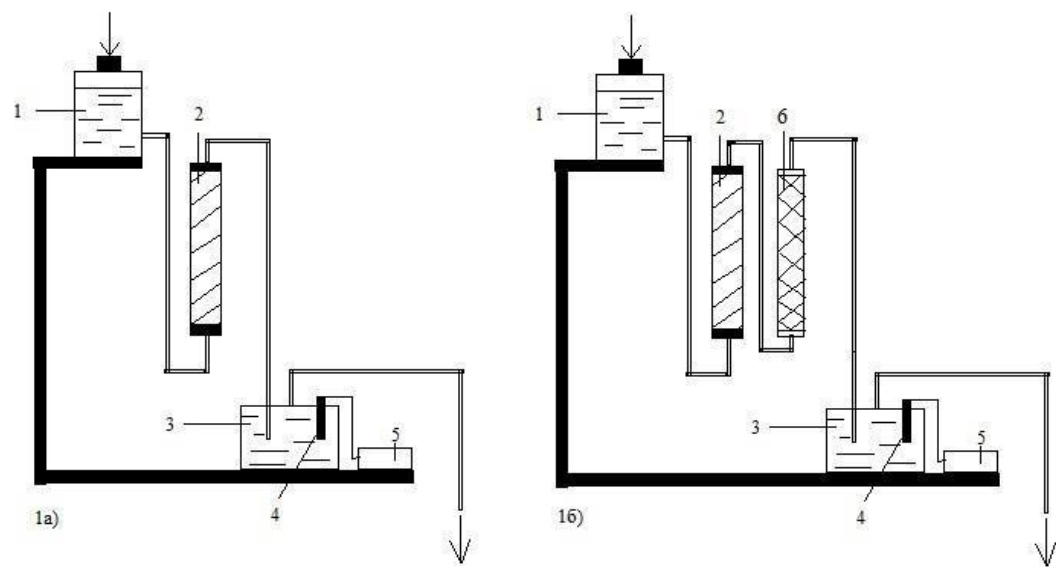

1 - ємність з водою; 2 - колонка з редокситом; 3 - ємність де розміщено датчик оксиметра Milwaukee MW600; 4 - датчик оксиметра; 5- оксиметр; 6 - колонка заповнена катіонітом або аніонітом

\section{Рисунок 1. Схема установки для знекиснення води (одноступенева(а), двоступенева(б))}

При проведенні досліджень на першому етапі через залізовмісний матеріал фільтрували водопровідну воду із швидкістю від 5 до 25 м/год, реакцію середовища якої доводили до рівня $\mathrm{pH}=6,7$ (рис.2).

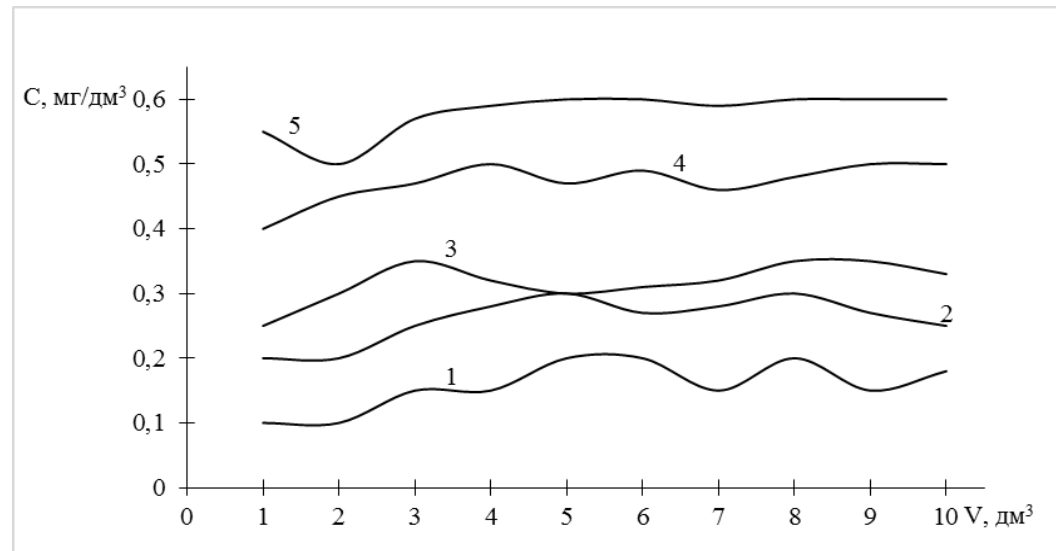

1 - швидкість фільтрування 5 м/год; 2 - швидкість фільтрування 10 м/год;

3 - швидкість фільтрування 15 м/год;4 - швидкість фільтрування 20 м/год;

5 - швидкість фільтрування $25 \mathrm{м} /$ год

Рисунок 2. Залежність концентрації кисню від пропущеного об'сму водопровідної води рН=6,7 через редоксит МЗ-Ф при різній швидкості фільтрування 
Як видно 3 рис. 2 концентрація кисню у воді при швидкості фільтрування 5 м/год знижувалась до 0,1-0,2 мг/дм³ . При збільшенні швидкості фільтрування до 25 м/год вміст кисню в обробленій воді зростав до 0,6 мг/дм ${ }^{3}$. При цьому ефективність видалення кисню ніяк не змінювалась при зростанні об'єму обробленої води. Слід відмітити, що в усіх дослідах використовували одне і те ж саме завантаження залізомісткого редокситу без будь-якої його регенерації.

Як це не дивно, але при підвищенні $\mathrm{pH}$ середовища до 8,5 (рис.3) ефективність вилучення кисню падала. Очевидно це пов'язано із зниженням швидкості розчинення металевого заліза при підвищенні $\mathrm{pH}$. Але враховуючи велику площу поверхні редокситу він все-таки забезпечував достатньо високу ефективність знекиснення води. При $\mathrm{pH}=8,5$ концентрація кисню знижувалась до 0,3-0,7 мг/дм³ при зростанні швидкості фільтрування від 5 до 25 м/год.

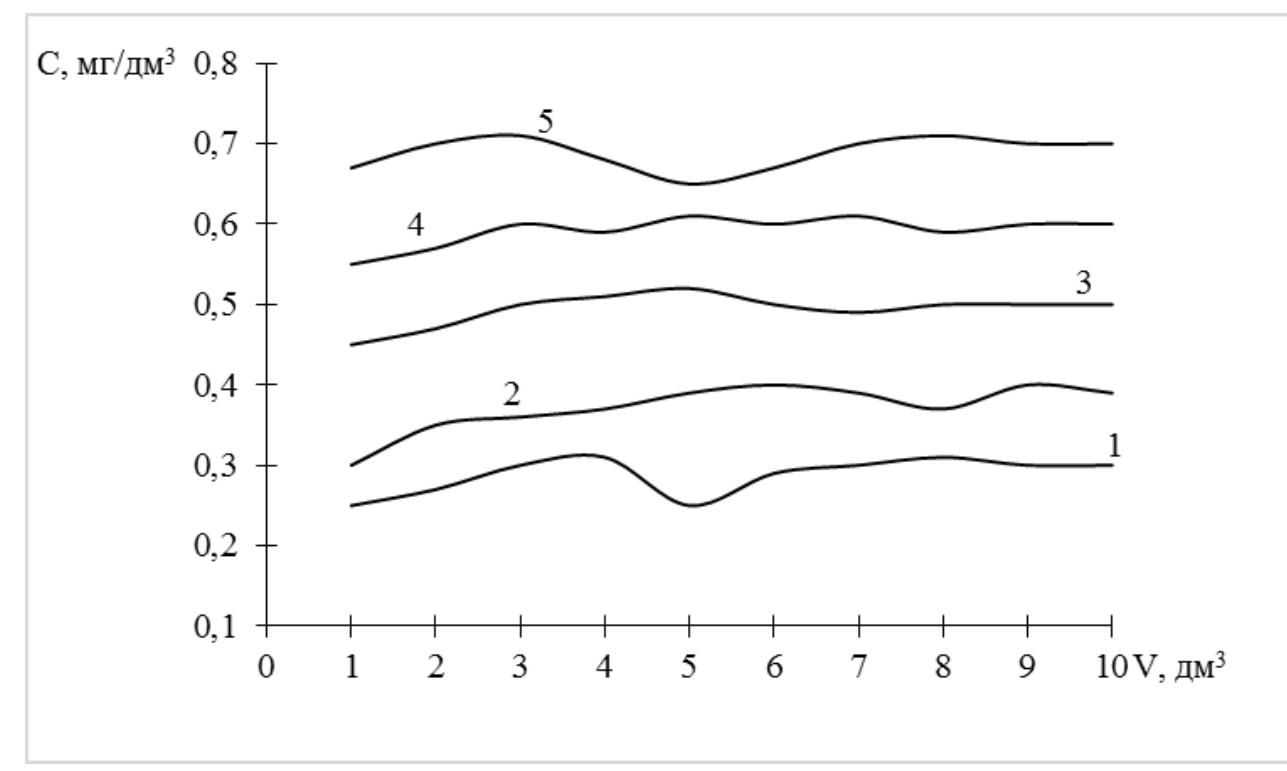

1 - швидкість фільтрування 5 м/год; 2 - швидкість фільтрування 10 м/год;

3 - швидкість фільтрування 15 м/год;4 - швидкість фільтрування 20 м/год; 5 - швидкість фільтрування $25 \mathrm{~m} / 2 о д$

Рисунок 3. Зміна концентрації кисню з об'смом профільтрованої водопровідної води $(\mathbf{p H}=8,5)$ через редоксит МЗ-Ф при різній швидкості фільтрування

Під час застосування двоступеневої системи стабілізаційної обробки спостерігається зменшення концентрації розчиненого кисню 3 8,05 до $0,05 \quad \mathrm{MrO}_{2} /$ дм $^{3}$ При швидкості фільтрування 5 м/год. Завдяки іонному обміну на катіоніті забезпечується видалення 3 води вторинного забруднювача - заліза. При цьому концентрація заліза зменшується 3 0,78 (відфільтрована вода після одноступеневої системи стаблізаційної обробки мала такий показник вмісту заліза) до 0,1 мг/дм³ ${ }^{3}$ Крім того. В результаті двостадійної обробки жорсткість води зменшується до нуля з подальшим іï зростанням вихідних значень через вичерпування ємності іоніту [3].

Варто зазначити, що підвищення ефективності видалення кисню відбувається шляхом його зв’язування при взаємодії з катіонами заліза (II), що сорбувались на катіоніті. 
При збільшенні швидкості фільтрування до 10 м/год вміст кисню зростає до 0,2 мг/дм³, що і прогнозувалось. При цьому також збільшується концентрація заліза у відфільтрованій воді зростає до 0,25 мг/дм³ . А от при використанні на другій стадії аніоніту в $\mathrm{SO}_{3}{ }^{2-}$ формі показники по концентрації заліза залишились незмінними, проте досягнуто повного вилучення кисню.

\section{Висновки.}

Показано, що підвищення швидкості фільтрування води через фільтр заповнений редокситом від 5 до 25 м/год при підвищенні рН середовища від 6,7 до 8,5 та 10,0 призводить до зниження ефективності зв'язування кисню $\left(\left[\mathrm{O}_{2}\right]=0,1-0,5\right.$ мг/дм ${ }^{3}$ при $\mathrm{W}_{\phi}=5 \mathrm{M} /$ год, $\left[\mathrm{O}_{2}\right]=$ 0,6-1,0 мг/дм ${ }^{3}$ при $\mathrm{W}_{\phi}=25$ м/год). В цілому залишкова концентрація кисню зростає від 0,2 до $1,0 \mathrm{мг} /$ дм$^{3}$.

Показано, що двоступенева стабілізаційна обробка, яка включає в себе знекиснення води та iї подальше натрій-катіонування, є більш ефективною. Вміст розчиненого кисню у воді зменшується порівняно з одностадійною обробкою до $0,59 \mathrm{MrO}_{2} /$ дм$^{3}$, при цьому вторинне забруднення води іонами заліза не відбувається. Одночасно з води видаляються іони жорсткості. У міру переходу іоніту в $\mathrm{Ca}^{2+}, \mathrm{Mg}^{2+}$ - форму ефективність вилучення заліза знижується.

Визначено залежність концентрації заліза та кисню при фільтруванні води послідовно через редоксит та катіоніт в $\mathrm{Na}^{+}$формі. Відмічено ефективне вилучення іонів заліза, жорсткості без суттєвого впливу на залишкову концентрацію кисню.

Показано, що послідовне використання редокситу МЗ-Ф та аніоніту АВ-17-8 в $\mathrm{SO}_{3}{ }^{2-}$ формі при знекисненні води забезпечує повне вилучення кисню із води при значному підвищенні фільтроциклу аніоніту в сульфітній формі через значне зниження кисню у воді на залізовмісткому редокситі.

\section{Література:}

1. Фрог Б.Н., Левченко А.П. Водоподготовка. Москва:МГУ. 1996. С. 680.

2. Cervova, J. Corrosive protection of metal materials in cooling water / J.Cervova, M.Hagarova, P. Lackova // American Journal of Materials Science and Application. - 2014. - №1 . - P. 6-10.

3. Гомеля М.Д. Знекиснення води за допомогою завантаження на основі залізомістких композитів / М.Д. Гомеля, М.М. Шуриберко, А.В. Голяка // Вчені записки Таврійського університету ім. В.І. Вернадського. - 2018. - Т. 29(68). - №6. - С. 64-69. 